\title{
Technology as a tool to enhance motivation and learning
}

\author{
Albertina Raposo ${ }^{1,}$ Anabela Durão ${ }^{1}$, Ana Estradas $^{1}$ and Ivana Ribeiro ${ }^{2}$ \\ ${ }^{1}$ Instituto Politécnico de Beja, Campus do IPBeja, 7800-295 Beja, Portugal \\ ${ }^{2}$ Unicamp-Universidade Estadual de Campinas, SP 13083-970, Brasil
}

\begin{abstract}
The aim of this work is to think about how technologies can have a role in motivation for learning. To respond to the necessary paradigm shift school faces, resulting from a different way of life in very recent past, the use of technology proves to be a powerful ally, ensuring student's ability to respond to technical and scientific questions as well as creating an environment of trust and security in classroom. Considering that we are at a critical turning point in technological evolution and changes seem irreversible. What new challenges does the teacher also face in this field? To understand what makes the activity and the class remarkable for students, we are using semistructured interview, focus group and questionnaire. Methods and technics used in the classes were diversified, and according to the intended goal. The use of these methods was not conditioned by technology but by the defined learning goals. Although this work is still beginning and needs to be continued, the results show that technology helps students to feel confident since it doesn't expose individual (un)knowledge, allows them to learn with pleasure, generates group dynamics and globally, creates happy moments that increase motivation and improve learning. Results show us that it is imperative to realize how much the teacher as an important integrative agent mediating between the real/virtual, technological/scientific, curriculum/skill, cognitive/emotional worlds.
\end{abstract}

\section{Introduction}

Nowadays, being a teacher is a matter of being focused on learning rather than teaching. With so much and so good information available and easily accessible, the figure of the "self-made man" can even lose meaning once it is easier to learn outside school. School, as an institution, must be equated as a space to promote learning and motivation to learn, which is often absent.

To respond to the necessary paradigm shift school faces, resulting from a different way of life in very recent past, the use of technology proves to be a powerful ally, ensuring student's ability to respond to technical and scientific questions as well as creating an environment of trust and security. Mobile phones, for example, are a powerful tool of continual use in the student's life. Even "the extent of change caused by recent and unexpected events like Brexit (Britain's departure from the European Union) will be insignificant compared to the impact of an avalanche of technological change that can reshape the very essence of humanity and life in our planet" [1]. And if, as Leonhard [1] says, the mega changes we are confronted with, will re-draw trade, culture and society, biology and ethics, what shall we say about school still working in a model created in the nineteenth century? Considering that we are at a critical turning point in technological evolution, where change seems irreversible, what new challenges does the teacher also face in this field? Also, it is important to remember that in this technological world where children belong, motivating them in the classroom, it is becoming increasingly difficult [2].

Another settled point is that learning (and learning with technology) does not just happen in the classroom, but anytime and anywhere. The integration and mobilization of the acquired knowledge can be done in the classroom, but also in the library, in school clubs, in active learning classrooms, in interdisciplinary and transdisciplinary contexts, such as peer-to-peer classes communicating between schools in different countries, collaborative work supported by virtual environments as pointed out by Meirinhos et al [3].

\subsection{Goal}

The aim of this work is to understand about how technologies can have a role in motivation for learning and academic success. Using the students' views as a starting point, in a context of formal education and disciplinary work, we tried to understand how can technological environments help students to develop their learning path in a more motivated way.

\subsection{The starting question}

As teachers, we defend that we must adjust methodology so it can serve learning. Same methods and technics may prove to be excellent or lousy according to multiple and

* Corresponding author: albertina@ipbeja.pt 
various factors. We often think we have the best class ever prepared, able to impress all students, and this just does not happen. Why? What mechanisms can make an activity remarkable and impactful? In this sense, we see technologies have been affecting profoundly education. As Morin [4] point out, we always connect formal learning with school and this means a specific place and time with classroom and school time schedule and curriculum. However, access to information brought up by new technologies, opens the door to learning spaces other than the classroom, while making virtual learning possible even in the classroom. This last aspect proves good results in increasing motivation and student autonomy [5]. Indeed, a study developed by dos Santos [5] on the introduction of technological interfaces as mediators of the teaching-learning process in the classroom context, shows a contribution in the gradual increase of motivation, autonomy, students' interest for the dynamics inherent in the discipline, and also for the promotion of student / student and teacher / student interaction.

\subsection{Facts and dilemmas}

For more than 30 years, Western countries have been trying to put digital technologies at the service of learning [3]. The policies for integration of technology in schools have been strongly driven by international organizations such as the European Union, OECD and UNESCO, which recognize the importance of such integration for learning, cognitive development and the development of skills needed to live in the digital society [3]. At the same time, the increasing development of technologies in all aspects of our days' life makes combating info-exclusion more than imperative has become a necessity and is therefore part of our daily tasks, to adapt the teaching-learning process to the perspectives of today's society and to make available the technological tools, in order to prepare students for an increasingly digital society [5]. In addition, classroom take advantage the fact that technological means constitute an important vehicle of motivation and promotion of autonomy, essential components to combat failure school. So, if teachers are able to develop in the classroom, strategies to implement innovative technological resources that fit the student's interests, this can be a help to better promote students' motivation and autonomy which seems to be very important in the learning process [6]. For Duarte [7] teachers must be open to the potential of new technologies and their integration into the classroom. But they should not resort to them just because others do or for fear of being considered backward and averse to change.

Being aware that there are no recipes in education and knowing that each case depends on several factors such as context, student's characteristics [5] or even teacher's characteristics, it is necessary to observe and clearly identify the eventual problem(s) in and try to find it's best solution(s) [7]. We know that in the global and informed society, educational institutions and education professionals are required to manage an increasingly: diverse population of students; communication, teaching, learning modalities and techniques, where digital literacy, intercultural online pedagogy and technological and intercultural competences play an increasingly important role [2]. This means the teacher is the one who must assume and decide also, what technologic tool(s) include, when, how and what for. So, as referred by Meirinhos et al [3] the need to adjust education systems to the demands of this new digital society, in particular as regards the curricular integration of digital technologies, cannot be done without, among other things, empowering teachers to do so.

If, as Casal (cit in Camacho [6]) says, teachers should expose students to challenging and structured situations in which they make a personal mental construction doing construtivist learning, then student's engagement with research and work bring a significative learning. But this point of view doesn't exclude the benefits of a first introduction to the scientific topic by the teacher [6].

It is known today that technologies are used as a potential methodological strategy for building collaborative knowledge but also promote effective reflection, which stems from interactive contexts articulating tacit and explicit knowledge and involving in the teaching-learning process teachers and students [2].

The lack of motivation both in students and/or in teachers is not a topic for this paper but it has been study in several studies. For some authors, like mentioned by [6] to understand the reasons why the lack of motivation appears allows to draw the better strategy to increase pleasure in learning and teaching. Research says that a motivated teacher with a motivated group of students can achieve more meaningful learning [2].

The mobile phone seems to be the technology that most adds value today: it is wireless and has quickly incorporated internet access; digital photography; communication programs (voice, TV); entertainment (games, mp3 music) and other services [4]. These changes brought by technology are such that the concept of school itself has to be re-equated since, as Morin states [4], local, fixed-time curriculum, do not have the same meaning and change the concept of classroom education and the distance education.

For today's kids, these gadgets are as natural as others in their daily lives. In fact, the use of information technologies sources, does not pose any obstacles to them, but rather is a constant challenge to the discovery of new learning [2].

A little bit of what has been expressed, can be summarized by Morin [4] "students are ready for multimedia, teachers in general are not. Teachers are becoming increasingly clear about technology mismatch and often try to hold on as much as they can by taking small compromises without changing the essentials. I think many teachers are afraid to reveal their difficulty in front of the student. That is why they maintain a repressive, controlling, repeating structure through habit. Teachers realize they need to change, but they are not sure how to do it and are not prepared to experiment safely." 


\section{Methodology}

To understand what makes the activity and the class remarkable for students, we used semi-structured interview, focus group and a short questionnaire asking about the preferences of the use of computer or mobile and advantages-disadventures from each one. In these data collection thirty (30) students participated. It is a very preliminary study and does not aim at the statistical treatment of data but rather, to validate opinions and feelings that result from our experience in the classroom.

The work on class, starts from both the experience and knowledge acquired and the pre-existing experiences by participants and it tries to be a space for the development of learning processes, based on a participatory format that privileges the exchange and sharing of experiences and combines content - concepts and themes - and methodological approaches linked to Global Citizenship, from a theoretical and practical point of view. Methods and technics used in the classes were diversified, and according to the intended goal. The use of these methods was not conditioned by technology but by the defined learning goals. Whether in participative techniques of active learning, simply active listening, informal dialogue, apps or quick research on google, all of the students' technological instruments were welcome. Students could use mobile or computer for Mentimeter exploitation purposes but they also use them for practical and dynamic activities such as a) environmental education, b) sex identification of chick, c) morphology of plants and d) Ecosystems and Biodiversity.

Mentimeter, is an interactive presentation's software (mentimeter.com) that appears as one more effective strategy to develop in class and motivate students.

Students that participate in this study were thirty, both from short level professional technical courses and graduation in Instituto Politécnico de Beja, Portugal.

\subsection{The use of Mentimeter}

Mentimeter is a digital resource available at mentimeter.com. The software, allows to create real-time interactive presentations and has three main possibilities combined with each other: 1) normal presentation, 2) presentation and sharing information or 3) expression of personal ideas and opinions. Mentimeter offers a) question type slides, b) quiz competition slides and c) quick slides. It also offers the possibility, in this 3 types, to choose different kinds and to introduce, or not, several options. Mentimeter also allows us to download results or just to reset them. Since each "player" can have a nickname, in quiz competition slides it is possible to the teacher to know wich student get the topic or not using for instance, the student number as nickname. Another interesting aspect is the possibility to create (anonymous) questions throughout the session that can be answered one by one as they arise or, at the end of the session.

\section{Results and discussion}

Although this work is still beginning and needs to be continued, the results from the different data collection sources used (interview, focus group and small questionnaire) show that the mobile phone is the most requested in class, and even for research, it is preferred over the computer. Of the 30 students who participated in the study, 25 prefer to use their mobile phones even when searching; 3 of them use their mobile phones more, but recognize that searching or making a text or presentation is better and easier than using the computer; for 2 of them, it is absolutely indifferent to use one or the other.

In general, results show us that technology helps students to feel confident since it doesn't expose individual (un)knowledge, allows them to learn with pleasure, generates group dynamics and globally, creates happy moments that increase motivation and improve learning. As Duarte [7] points out for high school "Everything that is new technology arouses enthusiasm, right from the start by the effect of the novelty. And using your cell phone today in a class activity can have the same motivating effect that powerpoint presentations had ten years ago. But after that effect, what matters is whether technology actually brings some enrichment to students' learning or is limited to an inconsequential and passing fashion." From our experience, in some cases, technology (e.g. some apps for identification of wildlife species) can also make no sense to the student if the contents are not pleasant for him/her.

Lessons learned, tell us that a considerable number of students shares lack of direction and focus in what concerns purpose; some of them put questions such as: what is the use of what I am learning? How useful is all of this in this society in the present time? It is imperative to face this and help students to deal with all these doubts, fears, anxieties and find a way to give meaning to their learning experiences. And of course, technology can be exploited for this, not just in a content-oriented sense but also in a motivational sense; without the two together, everything will remain inadequate.

Considering that the use of technologies is part of the students' daily life but, at the same time that it doesn't exclude the benefits of a first introduction to the scientific topic by the teacher [6], it is necessary to fit it into the teaching and learning process, and be able to take advantage of it potential as promoters of motivation and autonomy and significate practices and learning. To make this happen, its use in the classroom is fundamental and teachers must be aware how important it is for students to have and to overpower this digital tools and language. But more than on new technologies, changes on education depends on as Morin says [4] "having mature educators, managers, and students". Morin [4] put the emphasis on the need to be intellectually, emotionally, and ethically mature and to be a curious, enthusiastic open-mind person/teacher to be able to motivate and dialogue and create a rich learning environment. But for Duarte [7] despite that, teachers should not use new technologies if they are not comfortable with them or are not convinced that they represent an effective gain for learning for students. 
Far from thinking that the role of the teacher and the educator is less relevant in this modern society, it is now imperative to realize how much the teacher as an important integrative agent mediating between the real/virtual, technological/scientific, curriculum/skill, cognitive/emotional worlds. Teacher can be and shall be. a challenger of learning for each student and the one who can substantially contribute to a new generation capable in developing a better society.

\section{Acknowledgement}

Publication is funded by the Polish National Agency for Academic Exchange under the International Academic Partnerships Programme from the project „Organization of the $9^{\text {th }}$ International Scientific and Technical Conference entitled Environmental Engineering, Photogrammetry, Geoinformatics - Modern Technologies and Development Perspectives".

\section{References}

1 G.Leonhard, Technology vs Humanity - The Coming Clash Between Man and Machine, Portuguese edition. Tradução de Florbela Marques, Revisão científica de Carlos Fiolhais, depósito legal 430 857/2017, ISBN 978989-616-789-9, $1^{\mathrm{a}}$ edição Gradiva (2017)

2- S. Oliveira and M. Ribeiro, As tecnologias com potencial transformador em contexto educativo: realidade ou utopia? pp 222-230, IV Encontro Internacional de Formação na Docência (INCTE): Livro de atas,1203pp Bragança, 3-4 may ISBN 78-972-745259-0, handle http://hdl.handle.net/10198/15084 (2019)

3- M. Meirinhos, S. Rutz da Silva and R. Dessbesel, Modelos de integração curricular das tecnologias digitais em contextos de aprendizagem pp 102-112, , IV Encontro Internacional de Formação na Docência (INCTE): Livro de atas, 1203pp Bragança, 3-4 may ISBN78-972-745-259-http://hdl.handle.net/10198/15084 (2019)

4- J. Moran, A integração das tecnologias na educação, in Educação que desejamos: novos desafios e como chegar lá.5 a Ed. Campinas: Papirus, p. 89-90 (2013)

5- R. dos Santos, Promoção da motivação e da autonomia com recurso às tecnologias de informação e comunicação em alunos normovisuais e em alunos com deficiência visual, Relatório de Estágio Mestrado em Ensino de Informática, Universidade do Minho, Portugal (2015)

6- C. Camacho, Recursos Tecnológicos e Motivação para a Aprendizagem, Universidade Fernando Pessoa, Faculdade de Ciências Humanas e Sociais, Projeto de Investigação apresentado à Universidade de Fernando Pessoa para cumprimento dos requisitos necessários à obtenção do grau de Mestre em Docência e Gestão da Educação, Porto, Portugal (2017)

7- A. Duarte. O telemóvel na sala de aula https://escolapt.wordpress.com/2017/11/16/o-telemovelna-sala-de-aula/ (2017) 